\title{
Jakó Zsigmond
}

\section{Az erdélyi püspökség középkori birtokairól}

Közéleti befolyás és nagybirtok a középkori Európában mindenhol egymást feltételező, egymással összefüggő elemei voltak a politikai hatalom szerkezetének. A középkori európai államok a királyság és a és a keresztény egyház szoros szövetségében müködtek. Érdekközösségüknek megfelelően az uralkodók hatalmas birtokadományokkal támogatták legföbb szövetségesüket, az egyházakat, és a müvelt föpapságnak végig fontos szerepet biztosítottak a politikai életben, a legfőbb kormányzati szervezetek müködtetésében. Kiterjedt birtokaik révén az egyházak a gazdasági életnek is fontos tényezőivé válhattak. Az ország igazgatásának területi megszervezése is egyházigazgatás kereteihez igazodva épült ki. A fiatal magyar királyságnak tehát szintén érdeke volt, hogy a megszervezendő püspökségek müködését jelentős adományokkal elősegítse.

A fentiekböl is látható, hogy a középkori Magyarországi püspöki és káptalani uradalmainak alaposabb magismerése nemcsak az egyházi, hanem a világi társadalom, de különösképpen a politikai védőrétegek anyagi viszonyainak az eddiginél sikeresebb megközelítésére is lehetöséget kínál. Minthogy a régebbi szakirodalom némileg mostohán kezelte az egyházi nagybirtok kezdeteivel kapcsolatos kérdéseket, az alábbiakban az erdélyi püspökség uradalmainak kialakulásának bemutatásával szeretnők felhívni a figyelmet e vizsgálódások társadalom- és gazdaságtörténeti hasznára.

A kérdés jelentőségének érzékeltetésére elöre kell bocsátanunk, hogy a középkori Erdélyben a gyulafehérvári püspök és székeskáptalan végig egyike volt a legnagyobb birtokosoknak. Öket csupán az erdélyi vajdák múlták felül a salláriumukhoz tartozó királyi váruradalmukkal, de inkább csak birtoknagyság, semmint a jövedelmezőség tekintetében. A magyar királyság püspökségeinek jövedelméről 1185 és 1195 között készített kimutatás szerint a 2000 márkás évi bevétellel rendelkező erdélyi püspöknél csupán Esztergom (6000) és Kalocsa érseke (2500), valamint az egri föpásztor (3000) élvezett nagyobb jövedelmet. ${ }^{1}$ Amíg az átlagos magyar püspökségek évi jövedelme a középkor végén 16-17000 Ft örül mozgott, az erdélyi püspök javadalmát a velencei követek 1516 és 1523 között évi 20-24000 Ft-ra becsülték. ${ }^{2}$ A püspöki uradalmaknak az erdélyi gazdaságban és hatalmi struktúrában való súlya egy közepes nagyságú erdélyi megyéjével vetekedett. Pl. 1494-ben a püspök erdélyi birodalmainak behajtatlanul maradt adója $2643 \mathrm{Ft}$, Belső-Szolnok, illetve Doboka vármegye évi adóterhe pedig összesen 2806Ft, illetve 3102 Ft-ot tett ki. Ugyanekkor a püspök közép-szolnoki jószágai az egész megyére kivetett 2454 Ft adóból $550 \mathrm{Ft}$ befizetésével maradt el. ${ }^{3}$ Az egyházi nagybirtok tehát olyan fontosságú gazdasági és tényezője volt Erdély középkori fejlődésének, amellyel a tudományos igényü történetkutatásnak minden vonatkozásban fokozottan számolni kell.

Szent István és az őt követő első királyok a keresztény egyház megszervezése érdekében jelentős birtokokkal látták el a magyar püspökségeket. Az adományok a püspökség védöszentjének nevére szóltak, és a püspökök jó ideig csupán kezelöi voltak ezeknek a javaknak.

${ }^{1}$ Erdélyi Okmánytár. Codex diplomaticus Transsylvaniae. (Közzéteszi Jakó Zsigmond) Bp., 1997., 17 sz. (Ezután: CDTr.)

${ }^{2}$ A zichy és vásonkeői gróf Zichy család idősb ágának okmánytára. XII. (Közzéteszi Lukcsics Pál) Bp., 1931., 365. o. (Ezután: ZOkm.)

${ }^{3}$ Engel, Johann Christian: Geschichte des ungarischen Reichs und seiner Nebenländer. 1. Halle, 1797., 38. o. (Ezután: Engel.) 
A püspökök eredetileg olyasféle közösségben éltek udvari papjaikkal, akik kanonoknak neveztek, mint a szerzetesek apátjukkal. Egy fedél alatt, közös háztartásban, együtt zsolozsmáztak. Első királyainak a püspökségekkel egyidejüleg nem alapítottak káptalanokat is. Ezek a korábbi életközösségek felbomlásával, előbb a püspökök, majd a kanonokok különköltözése következtében, a XII. század második felétől kezdődően, fokozatosan alakult ki, és a XIII. század elején váltak független testületté, püspöki tanácsokká, külön jogi személyekké. Ezzel egyidejüleg indult el az addig közös vagyon felosztása, melynek során mind a püspökök, mind pedig a káptalanok önálló nagybirtokosokká váltak, akiknek azonban az anyagi érdekei gyakran egymással is ütköztek. ${ }^{4}$

A XII. század végétől fogva ismeretesek tájainkról anyagi indítású súrlódások püspökök és káptalanjaik között. Eredetileg a püspökök lévén a közös vagyon kezelöi, a különválás során igyekeztek a birtokból minél nagyobb és értékesebb részt maguknak megtartani. A XIII. században már Rómáig eljutottak az önállósult káptalanok panaszai szegénységük, anyagi gondjaik miatt. ${ }^{5}$ Érthető és természetes tehát, hogy az elosztás nyertesei általában a püspökségek lettek székeskáptalanaik rovására. Ezért különös, hogy Erdélyben az osztozásban legalábbis látszólag - a káptalan ját jobban, és a püspökök kényszerültek a székesegyház adománybirtokaitól teljesen függetlenül, azoktól területileg távoli uradalmakat kialakítani maguknak, melyekre káptalanuk már semmiféle jogigényt sem támaszthatott. Lehetséges azonban, hogy ez csak azért tünik így, mert a káptalané lett, akkor még alig lakott lévén, a püspöknek jutott jószágoknál területileg lóval nagyobb, de jövedelmezőség tekintetében azoknál sokkal értéktelenebbnek minősültek.

Írásos források hiányában ma már tisztázhatatlan, hogy mekkora volt és pontosan hol terült el ez az erdélyi püspökség megszervezésekor elnyert első helyi adománybirtok. Legfeljebb csak az valószínüsíthető, hogy ez nem lehetett összefüggő birtoktest Gyulafehérvár közvetlen környékén sem, hanem a települési viszonyokhoz igazodó egyes birtokokkal vagy birtokcsoportokból állhatott. Nagyobb uradalom kihasítását akadályozta, hogy a szervezés idején a Maros mentén még székely határőrök laktak, később pedig a szászok betelepítése szabott határt az egyházi birtokok terjeszkedésének. Egyébként az uralkodók már igen korán nyugati hospeseket is telepített a fehérvári várbirtokokra (Igen, Krakkó, Borbánd, Alvinc, Borberek). Sőt a Kecskekőre épített várral tartósították jelenlétüket és érdekeltségüket a püspöki székváros szomszédságában. A király vármegye szétbomlása folyamán a XII-XIII. században bizonyos falvak ugyan egyházi tulajdonba kerültek, de a püspökségen és a káptalanon kívül már egyes családok (Gáldiak, Gyógyiak, Váradjaiak) szintén részesültek a Gyulafehérvár környéki királyi birtok romjaiból. ${ }^{6}$

A püspökség birtokairól biztosabbat csak a tatárjárás utáni időktől fogva tudunk. Bár 1246ban a székhely körzetében csupán Gyulafehérvárt nevezik meg a föpásztor birtokaként, de a század második felében, a Maros mentén, még Sárd, Akmár, Berve és Szentkirály is a püspök

\footnotetext{
${ }^{4}$ Mindezekre 1. Békefi Remig: A magyarországi káptalanok megalakulása és Szent Chrodegang regulája. Bp., 1901., 25-33. o. - Gutheil Jenö: Az Árpád-kori Veszprém. Veszprém, 1977., 106-109. o.

${ }^{5}$ Codex diplomaticus Hungariae ecclasiasticus ac civilis. Studio et opera Georgii Fejér. II. Budae, 1830., 351-353. o. (Ezután: CDHung.) - Theiner Augustinus: Vetera monumenta historica Hungariam sacram illustrantia. I. Romae, 1859., 277., 289-290. o. (Ezután: Theiner: MonHung.) Békefi: i. m. 31-33. o. - Bunyitay Vince: A váradi püspökség története. II. Nagyvárad, 1883., 244. o. - Sugár István: Az egri püspökök története. Bp., 1984., 82. o.

${ }^{6}$ Györffy György: Az Árpád-kori Magyarország történeti földrajza. II. Bp., 1987., 107-108. o. és térképvázlatai.
} 
kizárólagos jószágaként szerepel. ${ }^{7}$ Ugyanekkor és ugyanezen a tájakon a káptalan már többszörösen nagyobb birtokot mondhatott magáénak. A püspök magának az egyházmegye székhelyének teljes területét is csak 1278-ban és 14289-ben szerezte meg a királytól. ${ }^{8}$ Györffy György mindezt azzal magyarázza, hogy a püspökök idejük nagy részét a királyi udvarban, állami-politikai szolgálatban töltötték, és ezért az osztozáskor az állandóan Gyulafehérváron tartózkodó káptalannak engedték a székhely körüli birtokok nagyobb részét. ${ }^{9}$

Bármi legyen is a XIII. század végére kialakult birtokviszonyok magyarázata, kétségtelen, hogy Erdély püspökei, legalábbis a tatárjárás óta, tudatosan igyekeztek önálló uradalmak kialakításával anyagilag függetleníteni magukat a káptalantól, illetve a vele közös és szinte állandó viták tárgyát alkotó tizedjövedelmektől. Erre az adott lehetőséget, hogy Kolozs vármegyében Gyalu, Közép-Szolnokban pedig Zilah és Tasnád már a nagy pusztítás előtt a püspökség tulajdonába került. Gál erdélyi püspök 1246-ban szerzett IV. Béla királytól e három település lakóinak igazságszolgáltatási kiváltságokat újranépesítésük meggyorsítása érdekében. ${ }^{10}$

E fenti birtokközpontok uradalmakká fejlesztését Monoszló nemzetségbeli Péter püspök (1270-1307) indíthatta el, noha ez okleveles adatokkal csupán a Kolozs megye birtokok esetében bizonyítható kétségtelenül. Péter püspök V. István király bizalmi embereként, annak ifjú királyi kancellárjából került Erdély egyházának élére. Politikai tapasztalatai és udvari összeköttetései nagymértékben segítették abban, hogy püspökségét anyagi tekintetben is a politikai hatalom erdélyi tényezőjévé tegye. A püspökség és a kolozsmonostori bencés apátság között a XIII. század elején lezajlott hatalmi harc felújulását véglegesen véglegesen megakadályozó szándék is vezethette, amikor 1270-1272 között adományul kérte a királytól a tatárok által elpusztított Kolozsvárt és környékét. ${ }^{11}$ Ezáltal ugyanis két tűz közé szorította az apátságot, és olyan birtokcserékre kényszerítette, melyek révén Kolozs megye nyugati felében összefüggő püspöki uradalmat alakíthatott. 1276-ban Piski (Hunyad vm.) és Akmárt (Fehér vm.) elcserélte a káptalan tulajdonában lévő Körösfővel (Kolozs vm.). ${ }^{12}$ 1282-nem már a Gyaluval szomszédos Kapus is püspöki birtok. ${ }^{13}$

Szászfenes hihetőleg Kolozsvárral egyidejü szerzeménye volt Péter püspöknek, és a város újratelepítése rendjén nyerhette szász, Tótfalu pedig szláv lakóit. ${ }^{14} 1291$-re kalotaszegi Vista és Sásság, valamint ugyancsak akkortájban Türe is betagolódott a püspöki uradalomba. ${ }^{15}$ Szintén az előbbi esztendőben bővítette Kolozsvár határát a szomszédos Lomb várjobbágyai birtokának megvásárlásával. ${ }^{16}$ 1298-ban a Szászfenessel és szomszédos Szászlónát úgy csatolta a gyalui vártartományhoz, hogy Marosújvárt és Faludi nevű birtokát adta érte cserébe Mikud bánnak és fiainak. ${ }^{17}$ Ezzel a birtokcserével kapcsolatosan kerülhetett Péter püspök

\footnotetext{
${ }^{7}$ CDTr I. 201., 348., 391., sz.

${ }^{8}$ CDTr I. 356., 450., sz.

${ }^{9}$ Györffy: i. m. II. 108. o.

${ }^{10}$ CDTr. I. 201. sz.

${ }^{11}$ Jakó Zsigmond: Társadalom, egyház, müvelödés. Bp., 1997., 136. o. - CDTr I. 298., 339., sz.

${ }^{12}$ CDTr I. 348. sz.

${ }^{13}$ CDTr I. 391. sz.

${ }^{14}$ CDTr I. 566. sz.

${ }^{15}$ CDTr I. 474., 591. sz.

${ }^{16}$ CDTr I. 489. sz.

${ }^{17}$ CDTr I. 566. sz.
} 
kezére a szomszédos Doboka megyében Hídalmás egy része, amelyen ezt követőleg új település jött létre Püspöki névvel. ${ }^{18}$ A királyi várbirtokok közül került át a püspökség uradalmába a Nádas melletti Daróc, Mákó és Gorbó. ${ }^{19}$ 1299-ben püspökség a régi vetélytársával, a kolozsmonostori apáttal is egyességre jutott olyan értelemben, hogy a püspöki birtokok közé ékelödött Szentgyörgy földért és Leske nevü havasért cserébe adta a bencéseknek a kalotaszegi Nádast és Boglártelkét. ${ }^{20} \mathrm{Ez}$ a csere tette lehetővé az uradalom további kiterjesztését a XIV-XV. században a gyalui havasok fokozatos benépesítése által. Így jöhettek létre a vártartomány román lakosságú hegyvidéki falvai: Egerbegy, Gorbófö, Hidegés Hévszamos, Sztolna és Oláhköblös. Amíg Kolozsvár 1316-ban vissza nem nyerte korábbi kiváltságos helyzetét, ott szándékozott kialakítani uradalma központját, és a város föterén építtetett palotaszerü püspöki lakóházat. Ez még 1355-ben is a püspökség tulajdonában volt, de amint kiszorult onnan, a birtok igazgatási központja a Szászfenes feletti csúcson emelt Leányvár, majd utóbb a gyalui vár lett. ${ }^{21}$ De azért még 1366-ban is éltek Kolozsváron püspöki jobbágyok. $^{22}$ A gyalui uradalom fentebb ismertetett törzsterülete többé nem változott lényegesen egészen a XVI. század közepén bekövetkezett szekularizációig, amikor is a vártartomány kincstéri-fejedelmi javadalommá alakult. ${ }^{23}$ Ez persze nem jelenti azt, hogy egyes falvak zálogosítás útján sem szakadtak ki belőle ideiglenesen, vagy a szomszédos birtokból egyesek nem kerültek be átmenetileg a gyalui püspöki uradalomba.

Péter püspök birtokszerző fáradozásait hozzá hasonló céltudatossággal a Balog nemzetségbeli Szécsi András püspök (1320-1356) folytatta. Erre különösen jó lehetőségei nyíltak, mivel Dénes és Pál nevü két testvér volt a sikeres katonai vezetője azoknak a harcoknak, amelyeket I. Károly király indított, hogy visszafoglalja Erdélyt a lázadó oligarcháktól. ${ }^{24}$ Szécsi Pál el is esett ezekben a harcokban, de családjának több tagja szintén a király legmegbízhatóbb hívének számított. ${ }^{25}$ Érthető tehát . hogy mindjárt a király első katonai sikerei után 1317-ben éppen Szécsi András került prépostként az erdélyi káptalan élére, majd pedig 1320-ban ő lett Erdély püspöke. Jóllehet XXII. János pápa a káptalan választását előbb azzal az indoklással, hogy András prépost a tudományokban kevéssé járatos, 27 éves fiatalember, megsemmisítette ugyan, de később a király és az ország vezetőinek nyomatékos ajánlására, valamint önmagának és családja tagjainak az erdélyi ügyekben szerzett különleges érdemeire való tekintettel mégis kinevezte püspöknek. ${ }^{26}$ Szécsi András személyében tehát Péterhez hasonlóan inkább politikus nagyúr, mint papi lelkületü, kegyes személy az erdélyi püspöki székben. Az új

${ }^{18}$ Béke Antal: Az erdélyi káptalan levéltára Gyulafehérvárt. Bp., 1889-1895. (Klny a Történelmi Tár megfelelő évfolyamaiból.) 194 .sz. (Ezután: ErdKLt.) - DF 277399.

${ }^{19}$ Csánki Dezső: Magyarország történelmi földrajza a Hunyadiak korában. V., Bp., 1913., 294-295., 344. o. (Ezután: Csánki.)

${ }^{20}$ CDTr I. 583-584. sz.

${ }^{21}$ Documenta Romaniae Historica. C, Transilvania. X. Bucureşti 1977., 385. (Ezután: DocRomHist.) - DF 277333. - ErdKLt 657. sz.

${ }^{22}$ Csánki V. 311.

${ }^{23}$ Jakó Zsigmond: A gyalui vártartomány urbáriumai. Kolozsvár, 1944., XXVIII-XXX.

${ }^{24}$ Engel Pál: Az ország újraegyesitése- I. Károly küzdelmei az oligarchiák ellen (1310-1323) Szinán. 122/1988., 111., 129-130. o.

${ }^{25}$ Rokoni összeköttetéseire 1. Karácsonyi János: a magyar nemzetségek a XIV. század közepéig. I. Bp., 1900., 175. o.

26 Temesváry János: Erdélyi középkori püspökei. Cluj-Kolozsvár, 1922., 141-147. o. (Ezután: Temesváry.) Theiner: MonHung, I. 465-467. o. 
püspök pedig, legalábbis szervezett síkon és anyagi tekintetben rendet kívánt teremteni a reábízott egyházmegyében. Eszközeiben ugyan nem volt válogatós, de kitartó és következetes munkájával maga is tagadhatatlanul hozzájárult Erdélyben a jogrend helyreállításához. valóságos versenytársa lett Erdély stabilizálásában Szécsényi Tamás vajdának, akivel összeütközésbe is került. Szécsi András püspök a több mint fél évszázados anarchia után a rendezett viszonyok helyreállításában, az erdélyi egyházon belül, ugyanazt a szerepet játszotta, mint Szécsényi Tamás vajda a tartomány politikai és jogi élete területén. A hatalom két erdélyi tényezőjének konfliktusai szükségszerüen következtek abból, hogy mindketten másokra való tekintet nélkül, eröszakos eszközökkel törtek céljaik elérésére,

Szécsi András az egymást váltó vajdákkal egyenrangú politikai-hatalmi tényezőnek, a stabilitás állandó erdélyi biztosítékának tekintettel saját méltóságát. Ennek a szerepnek az ellátásához azonban tovább kellett erősítse püspökségének anyagi alapjait. Ezt a célt az anarchia idején elidegenedett egyházi birtokok visszaszerzésével, Péter püspök kezdeményezéseinek folytatásával, és azáltal kívánta elérni, hogy újabb szerzeményekkel csökkenti a káptalan birtokok túlsúlyát a püspöki székhely körzetében. Fenti céljai elérésére a király bizalmas híveként minden lehetősége meg is volt.

András püspök az elidegenedett egyházi birtokok, tizedek és egyéb jövedelmek visszaszerzésére 1327-ben pápai és királyi támogatással indított akciót. Ennek során, közel egy évtizeden át tartó szívós munkával, sikerült rendezni az egyházi tizedfizetés ügyét mind a szászok, mind pedig a földesurak, mind pedig a papok vonatkozásában. ${ }^{27} \mathrm{Az} 1350$-es években pedig a püspökség birtokaira vonatkozóan a szomszédos hiteleshelyeknél található oklevelek átíratásával igyekezett véglegesen tisztázni azok jogi helyzetét. ${ }^{28} \mathrm{~A}$ közép-Szolnok megyében formálódó tasnádi és zilahi püspöki uradalom népesedését azzal szándékozott előmozdítani, hogy számukra már 1327-ben bíráskodási kiváltságot szerzett a királytól. ${ }^{29}$

A Péter püspök által kialakított gyalui vártartományt viszont újabb birtokok szerzésével bővítgette a szomszédos megyék irányában. Pl. 1338-ban a Doboka megyei Mikó, Szili és Kovács birtok felét azzal a feltétellel vette zálogba, hogy a kiváltás idejének elmulasztása esetén a tulajdonos azokat köteles neki elörökíteni. ${ }^{30} \mathrm{~A}$ fenti birtokok területén, Hídalmás közelében sikerült Püspöki névvel új települést alakítania. Az elöbbiekkel volt szomszédos az a Homorodszentmihálytelket, melyet András püspök 1343-ban, és Köblös, melyet a következő években részletekben szerzett meg Kolozs megyei uradalma részére végrendeli hagyatékként, illetve vásárlás útján. ${ }^{31}$ Ehhez a gyalui vártartomány kiegészítéseként Doboka és Kolozs megye határvidékén formálódó birtokcsoporthoz a püspök 1344 és 1352 között, hasonló módon, megszerezte Esztényt, Csomafája negyedét és Marót. ${ }^{32}$ Légen megszerzésére tett kísérlete pedig azt mutatja, hogy András püspök Kolozs megye mezőségi részében, illetve Kolozs-

${ }^{27}$ Ttár 1887., 622-623. o - Zimmerrmaann, Franz-Werner, Carl: Urkundenbuch zur geschichte der Deutschen in SiebenbürgenI I. Hermannstadt 1892., 419-428., 433-435., 462-463., 469-471. o. (Ezután: Ub.) - DL 36297.

${ }^{28}$ Ub II. 85. o. - DF 277322.

${ }^{29}$ DL 30617.

${ }^{30}$ Szabó Károly: Az Erdélyi Múzeum eredeti kivonata (1232-1540). Bp., 1889., 56. sz. Llny a Ttár 1889-1890. évfolyamából. (Ezután: EMOk1.)

${ }^{31}$ Documente privind istoria României. C. Transilvania, veacul XIV, vol. IV. Bucureşti, 1955., 612613. o. (Ezután: DIR C.) - DocRomHist, C. X. 289-291. o.

${ }^{32}$ DIR C, veacul XIV, vol. IV. 618-619., 625-626. o. - DocRomHist, C, X. 45-47., 146-147. o. 
vártól délre, Bányabükk irányában is igyekezett megvetni a lábát. ${ }^{33}$ A gyalui uradalom törzsterületét a későbbi püspökök is igyekeztek új szerzeményekkel bővítgetni. Ahova egyszer akár zálogos birtokosokként beférkőzhettek, ott utódaik is terjeszkedni próbáltak. Pl. István püspök 1410-ben zálogbirtokot szerzett a gyalui vártartománnyal határos Kóródon. ${ }^{34}$ Ugyanott, valamint Vásártelkén és Lapupatakon Várday Ferenc 1521-ben, Statileo János püspök pedig még az 1530-as években igyekezett újabb részeket megszerezni. ${ }^{35}$ Hasonló céltudatosság jellemzi Szécsi András arra irányuló törekvését is, hogy a püspöki székhely körzetében növelje birtokai számát. ebben I. Károly király életében még az igeni és krakkói hospesekkel szemben is számíthatott támogatásra. ${ }^{36}$ Szécsényi Tamás vajdával és I. Lajos királlyal való kapcsolata azonban már korántsem volt ilyen harmonikus, sőt nyílt összeütközésre is sor került közöttük. ${ }^{37}$ Ezt a célját a püspök zálogbavételen és vásárláson kívül úgy igyekezett elérni, hogy gyermektelen nemeseket vett rá, lelki üdvösségük biztosítása reményével, birtokaiknak a püspökségre való hagyományozására. Ilyen irányú buzgólkodása azonban akkora ellenkezést váltott ki az erdélyiek körében, hogy I. Lajos király a püspökkel támadt jogviták rendezése során kénytelen volt úgy rendelkezni, hogy András püspök Erdély területén királyi engedély nélkül egyetlen nemes birtokát sem foglalhatja el vagy vásárolhatja meg. ${ }^{38}$ A püspök azonban birtokai kiterjesztését, hogy Gyulafehérvár környékén is megvalósíthassa terveit.

Mindenekelőtt a Péter püspök által 1298-ban Szászlónáért elcserélt Marosújvárt szerezte vissza Mikud bán fiaitól. 1338-ban előbb csak zálogba vette, majd 1342-ben örök áron megvásárolta. ${ }^{39}$ Ezzel egyidejü, de új szerzeménye volt a közeli Csombord és Gombás felerésze, valamint ez utóbbi határában telepített Apahida nevű román falu. Mindhárom birtokot gyermektelen tulajdonosaik lelki üdvösségük biztosítása érdekében haláluk esetére eleve az egyháznak szánták, de a püspök azzal siettette a jogügylet befejezését, hogy a távoli Harinát, Bilakot és Nécet használatra életük végéig átengedte az adományozóknak. ${ }^{40} \mathrm{~A}$ fentiekkel együtt kerülhetett, de zálogként András püspök kezébe Hejőd, Acintus és Nándorlaka, míg a Torda megyei Lapádot, Lázot és Rákost Szécsényi Tamás vajda fia 1354-ben adományozta a püspökségnek szüleik lelki üdvösségének biztosítására. ${ }^{41}$ Enyed körzetében tehát András püspöknek sikerült összefüggő, tekintélyes kiterjedésü birtokcsoportot egybekovácsolnia, melyet aztán utódai is lehetőség szerint bővítettek. Pl. Statileo János püspök még 1354-ben is szerzett újabb részeket Csombordon. ${ }^{42}$

${ }^{33}$ DIR C, veacul XIV, vol. IV. 637. o.

${ }^{34}$ ErdKlt 242-243. sz. - Mályusz Elemér (kiad.): Zsigmondkori oklevéltár. II., Bp., 1951., 7475. sz. (Ezután: ZsOk1.)

${ }^{35}$ ErdKlt 450., 834-835., 864. sz. - Jakó Zsigmond (kiad.): A kolozsmonostori konvent jegyzökönyvei, 1289-1556. I-II. Bp., 1990., 4036., 4356., 4469., 4474., 4482. sz. (Ezután: KmJkv.) - Beke Antal: A kolozsmonostori konvent levéltára. Bp., 1898., 395-399., 404. sz. (Ezután: KmLt.)

${ }^{36}$ Barabas Samu (kiad.): A római szent birodalmi gróf széki Teleki család oklevéltára. I. Bp., 1895., 56-57. o. (Ezután: TelOkl.)

37 Theiner: MonHung I. 644-645. o. - Nagy Imre-Tasnádu Nagy Gyula (kiad.): Anjou-kori okmánytár. V. Bp., 1887., 337-338. o. (Ezután: AOkm.)

${ }^{38} \mathrm{Ub}$ II. $21-23$. o.

${ }^{39}$ DF 277283. - ErdKLt. 632-633. sz. - DIR C, veacul XIV, vol. III. 595-596., 598-600. o.

${ }^{40}$ TelOkl. I. 77-81. o. - Ub II. 7-8. - DF 277297.

${ }^{41}$ UbII. 141-142.o - DocRomHist C, X. 265-266. o. - DF 277331.

${ }^{42}$ ErdKLt 486-487. sz. 
A fentiekkel egyidejüleg András püspök a székhelye tőszomszédságában is bővítgette a püspökség birtokait. 1344-ben zálogba vette a Berve szomszédságában lévő Herepét, Fahíd megszerzésével pedig hídfőállást épített ki a Gáldiak területén való terjeszkedéshez. ${ }^{43} 1348$-ra sikerült a püspöknek elérnie, hogy a Gáldi család gyermektelen tagjai - rokonaik tiltakozása ellenére - elődeik és maguk lelki üdvének biztosítása véget .. Gáld ötödét, valamint Fahídon, Gáldtőn, Medvésen és Sünetelkén őket illető részekre vonatkozóan a püspökség javára tegyenek hiteleshelyi bevallást. ${ }^{44}$ András püspök halála (1356) után a magukat megrövidítetteknek tekintő családtagok megtámadták ugyan ezt az adományt, de a király az egyház javára döntötte el a jogvitát, és ezzel megszilárdította a püspöki birtoklást Gyulafehérvár környékén. ${ }^{45}$ Mindezt az is előmozdította, hogy Szécsi András halála után unokaöccse, Szécsi Domokos (1357-1368) lépett helyére, aki már évtizedek óta a székeskáptalan prépostjaként részt vett az egyházkormányzásában. ${ }^{46}$ Meghatározó következményekkel járt az erdélyi püspökség középkori birtokviszonyainak alakulására, hogy fél évszázadon át, 1317 és 1368 között a politikai vezetőréteg egyik legbefolyásosabb családjának tagjai szinte magántulajdonukként tekintették a méltóságukkal járó vagyont, de egyben védelmezték is az erdélyi egyház anyagi érdekeit. A Szécsiek politikai befolyásának és gazdasági súlyának is szerepe lehetett abban, hogy az erdélyi birtokviszonyok rendezésére 1363 és 1377 között kiküldött királyi bizottságok egyik legtekintélyesebb és legállandóbb tagja éppen Szécsi Miklós horvátdalmát bán volt. ${ }^{47}$ E rendezés során a király 1366 . július 8 -án nemcsak jóváhagyta a püspökség és a káptalan javára tett birtokadományokat és hagyatékokat, hanem kifejezetten megengedte, hogy Szécsi Domokos püspök és utódai, valamint az erdélyi káptalan bárkitől elfogadhassanak birtokokat és végrendeleti hagyatékokat. ${ }^{48}$ 1369-ben abban a különleges kegyben is részesítette az erdélyi püspököket, hogy határper és birtok visszaperelése esetén csak a szomszédok legyenek kötelesek okleveleket bemutatni, míg a püspökök jobbágyaik vallomásával is bizonyíthassanak. ${ }^{49}$

A XIV. század második felében tehát, elsősorban Szécsi Andrásnak és Domokosnak köszönhetően, létrejött az erdélyi püspökség Maros-menti és Gyulafehérvár-környéki uradalma, melynek kiterjedése két évszázadon át, egészen a szekularizációig lényegesen már nem változott. Legfeljebb kisebb szerzeményekkel ás új településekkel kiegészült. Pl. 1390-bwen végrendeletileg a püspökségre szállt lapádi és csombordi birtokával szomszédos Alsó- és Felső Bagó egy része, ${ }^{50}$ 1440-ben pedig Lépes György püspök Becét, Vadvermet és Újfalut szerezte meg. ${ }^{51}$

A tatárjárás utáni újrakezdéskor az erdélyi püspököknek Kolozs, Doboka és Szolnok vármegyében voltak székhelyüktől távoli birtokai. ${ }^{52}$ Ezek közül a dobokai Harina és Bilak uradalommá való kikerekítéséröl a méltóságuk hatalmi-politikai súlyát anyagilag megalapozó

\footnotetext{
${ }^{43}$ DIR C, veacul XIV, vol. IV. 624-625., 636-639. o. - DF 277301., 277303., 277323., 277326.

${ }^{44}$ Ub II. 52-55. o. - Aokm V. 180-181. o.

${ }^{45}$ Ub II. 141-142. o. - D1 32197. - DocRomHist C. XI. 205-206., 243-245. o.: XIII. 84-90. o.

${ }^{46}$ Temesváry: i. m., 148-175. o.

${ }^{47}$ Ub II. 472-473. o. - DocRomHist C. XIII. 270-210. o - DL 5476., 28750., 30397.

${ }^{48}$ DocRomHist C. CIII. 177-178. o. - DF 277369.

${ }^{49}$ DocRomHist C. XIII. 576-579. o. - DL 30397

${ }^{50} \mathrm{ZsOk1} \mathrm{I.} \mathrm{1703.} \mathrm{sz} \mathrm{-} \mathrm{DF} 277421$.

${ }^{51}$ ErdKlt 704. sz.

${ }^{52}$ CDTr I. 201. sz.
} 
püspökök eleve lemondtak. Harina és Bilak már Szécsi András elképzelésében is csak ideiglenesen átengedhető cserebirtokként jött számításba Gombás és Csombord megszerzése idején. ${ }^{53}$ Végül is ezeket a birtokait a püspökség arra használta fel, hogy feláldozásukkal megszabaduljon a vajdák kényelmetlen közelségétől, amit a Kecskekő várában székelő várnagyai jelentettek számára. A Zsigmond királlyal létrejött megállapodás értelmében e dobokai birtokaiért cserében a püspökség megkapta a székhelye tőszomszédságában lévő vajdai várat. ${ }^{54}$ Ezzel megoldást nyert az a káptalannal is sok súrlódásra okot adó helyzet, hogy Péter püspök által emelt Szentmihálykő vára káptalan területen állott. ${ }^{55}$

Az erdélyi püspökség Meszesen túli részei és joghatóságú igényei szempontjából, de gazdasági okokból is különösen fontos volt a mai Szilágyság területén lévő Zilah és Tasnád birtoklása. Ezekhez a jószágaihoz Gyulafehérvár püspökei egészen a szekularizációig ragaszkodtak, mert - legalábbis a XVI. század közepén - ebből a két mezővárosból és tartozékaiból került ki jövedelmük nagyobbik része. ${ }^{56}$ A Meszesen túl is a két Szécsi alakította ki a püspöki uradalmakat a fentebb már bemutatott módszerekkel: tehát királyi támogatás mellett vásárlásokkal, cserékkel, vallásos szempontokra hivatkozva.

A két Szécsi püspök és utódaik fáradozásait az alföldi jellegü Érmelléken koronázta nagyobb siker. A tasnádi uradalom kialakulásának részleteiből ugyan csak annyi ismeretes, hogy Szécsi András 1345-ben a Kolozsvár piacán álló püspöki házát és ottani szőlöjét adta cserébe Kegye birtok feléért, mellyel Tasnád tartozékait kívánta növelni. ${ }^{57}$ Utódai is hasonló módon járhattak el Tasnád tartományának kialakítása során. Pl. István püspök 1406-ban a Torda melletti Szentmiklóst adta cserébe Zsigmond királynak, hogy Tasnádhoz csatolhassa Cégényt és Kisnagyfalut. ${ }^{58}$ Máté püspök viszont 1453-ban a szomszédos Kenén igyekezett megvetni a lábát. ${ }^{59}$ Miklós püspök pedig 1467-ben a közeli Csőrgöt vásárolta meg véglegesen. ${ }^{60}$ Geréb László püspök 1496-ban nemcsak a Tasnáddal tőszomszédos és Szilvással, hanem a szántói Becskiek Szatmár megyei közeli jószágaival is igyekezett gyarapítani kedvenc uradalmát. ${ }^{61}$ Ugyanezt tette Várday Ferenc püspök is, amikor 1520 körül a szintén Szatmár megyei Vezenden és Mezőpetriben szerzett zálogos jószágot. ${ }^{62}$

Közép-Szolnok vármegye 1475 körüli adóösszeírásaiban az erdélyi püspök az 54 Ft-ot fizetö Tasnádon kívül Magyar- és Közép-Csaholyon 1-1 Ft, Csőgön 15 Ft, Kisnagyfalun 22 Ft és Cégényben $13 \mathrm{Ft}$ adóval szerepel. ${ }^{63}$ A térképre tekintve, látható, hogy ekkorára az erdélyi püspököknek terjedelmes uradalmat sikerült kialakítaniok ezen a termékeny síkságon. Tasnád lett az egyházmegye Meszesen túli részének igazgatási központja. Itt székelt a gyulafehérvári püspök helynöke, de kedvenc tartózkodási helye lett, legalábbis a XV. század végétől fogva

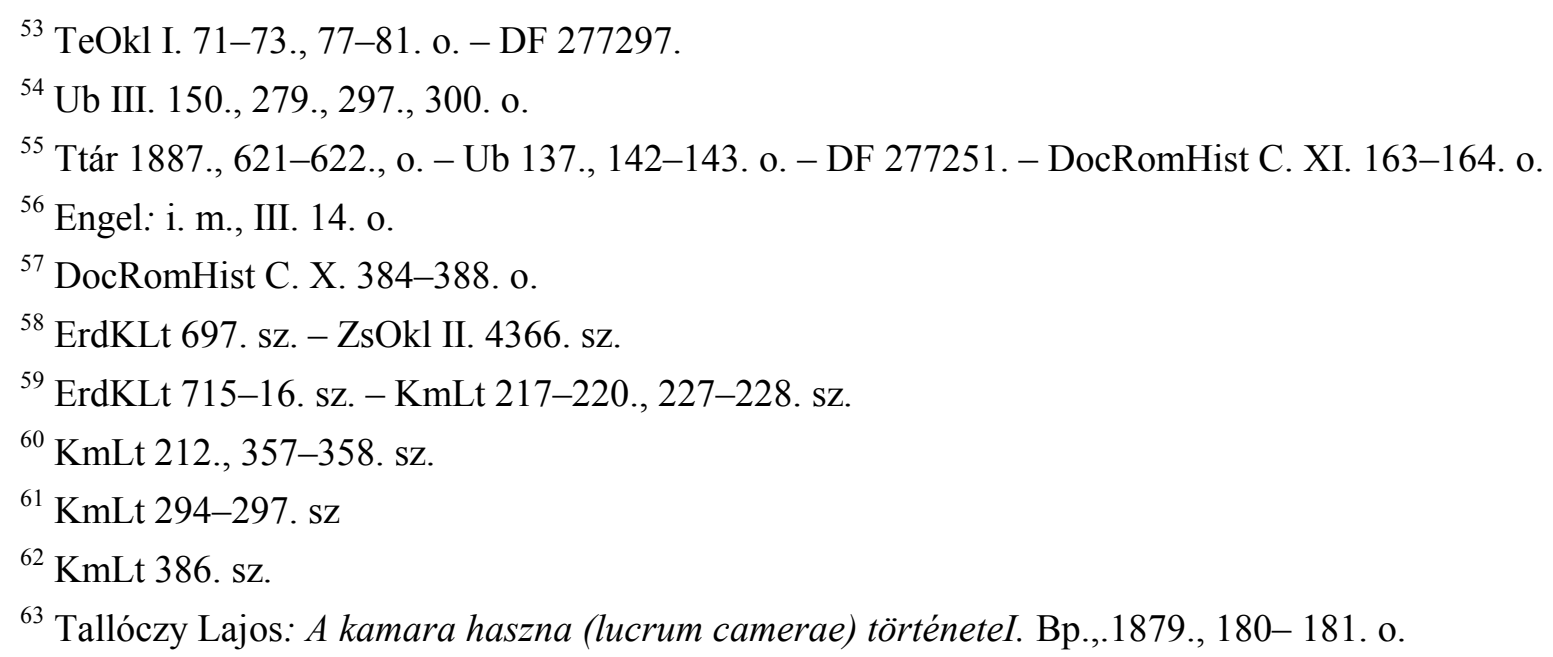


maguknak a püspököknek is. Főként Geréb László (1475-1501) és Várday Ferenc (15131524) püspök időzött itt szívesen és gyakorta. ${ }^{64}$ 1474-ben Mátyás király azt is engedélyezte a püspöknek, hogy Tasnád fából vagy kőből várat építsen magának. ${ }^{65}$ Erre ugyan nem került sor, de az itteni püspöki kúria, a gyalui és szentmihálykői vár mellett a püspöki birtokok harmadik fontos központjává nőtte ki magát. ${ }^{66} \mathrm{E}$ mezőváros gazdasági súlyát jól kifejezi a XVI. század közepéről reánk maradt adóösszeírások. Ezek szerint 1543-ban Tasnádon 55 és fél portát, 6 zsellért, 6 szabadot, 80 szegényt és 14 elhagyatott házat írtak össze. 1549-ben viszont ugyanitt 70 portát, 103 szegényt, 50 új házat, 18 papi házat és 11 szolgát számláltak az összeírók. ${ }^{67}$

Zilah is tatárjárás elötti szerzeménye volt az erdélyi püspököknek, és hihetőleg még a XII. században királynői tulajdonból kerülhetett az erdélyi egyház birtokába. Ezt azért kell feltételezni, mert az itteni vámjövedelem felöl még 1281-ben is a királyné rendelkezett. ${ }^{68}$ Szécsi András ebben az esetben is csere útján és vallásos meggondolásokkal sugallva kezdte el Zilah körül a püspöki uradalom kialakítását Szolnok és Kraszna vármegye határán. 135-ben egy zilahi szabad telekét cserében részbirtokot szerzett a közeli Kecelen, és többek tiltakozása ellenére megvetette lábát ezen a területen. ${ }^{69} 1349$-ben egy gyermektelen öregasszony hagyta, üdvössége biztosításának reményében, báldoni birtokrészét András püspökre és utódainak. ${ }^{70}$ Ezzel Zilahtól északra is elindította a terjeszkedést. Ez késztethette Máté püspöki, hogy 1452ben a szomszédos Balla megszerzésére is kísérletet tegyen. ${ }^{71}$ Talán még Szécsi András kebelezte be a püspöki uradalomba a Zilahhal és Kecellel egyaránt tőszomszédos Pálvárát és Kisrécsét, de ezeket 1359 és 1362 között utódjától, Szécsi Domokostól visszaperelték azon a címen, hogy a püspök jogtalanul, erővel foglalta el azokat. ${ }^{72}$ Ennek ellenére 1391-ben már mindkét települést újra az erdélyi püspökség birtokolta zálog címén. ${ }^{73}$ De Kecelen is 1498-ban és 1520-ban szintén terjeszkedett a püspökség. ${ }^{74}$ Cigányt és Vaját 1411-ben István püspök Aranyos vára felbomlóban levő tartományából vásárolta meg a kusalyi Jakcs család tagjaitól. ${ }^{75}$

Közép-Szolnok vármegye adójának 1475/6 körüli kimutatásában Zilah 169 Ft-tal, Cigányvaja 22 Ft-tal, Goroszlófalva 3 Ft-tal, Magyar-Egrespatak 19 Ft-tal, Román-Egrespatak pedig 14 Ft-tal szerepel. ${ }^{76}$ ebben a kimutatásban természetesen nincsenek benne Zilah Kraszna megyébe eső tartozékai. Zilah népességét és gazdasági jelentőségét tekintve felülmúlta a tasnádi uradalomét, noha tartozékainak kiterjedése szerényebb volt amazénál. Zilahon 1543-

\footnotetext{
${ }^{64}$ Zokm XII. 381., 400., 402. o. - ErdKLt 760. sz.

${ }^{65}$ ErdKLt 730., 760. sz.

${ }^{66}$ Engel: i. m. III. 14. o.

${ }^{67}$ Maksay Ferenc: Magyarország birtokviszonyai a XVI. század közepén. I. Bp., 1990., 401-428. o. Magyar Országos Levéltár, Magyar Kamara Levéltára, Conscriptiones portarum 60. kötet, Itt az uradalom többi falvainak adatai is megtalálhatók.
}

${ }^{68}$ CDTr I. 11., 253., 389. sz. - DF 277418.

${ }^{69}$ DIR C, veacul XIV, vol. IV. 640-641. o. - DocRomHist C. X. 278-279. o. - DL 31091., 40994.

${ }^{70}$ DIR C, veacul XIV, vol. IV. 688-689. o.

${ }^{71}$ ErdKlt 711. sz.

${ }^{72}$ DocRomHist C. XI. 432-433., 449-452. o.; XII. 97-102. o. - DL 62715.

${ }^{73}$ DF 277422.

${ }^{74}$ ErdKlt 444., 446., 756., 758., 765-766. sz. - KmLt 331. sz.

${ }^{75} \mathrm{ZsOkl}$ III. 722., 839., 958. sz.

${ }^{76}$ Tallóczy: i.m., 184-185. o. 
ban 90, 1549-ben pedig 75 portát írtak össze, 1553-ban viszont a háborús pusztítások következtében már csak 51 és fél portát, továbbá 53 lerombolt és 11 új házat, 6 nemesi kúriát és 23 elhagyott telket találtak az egykori virágzó mezővárosban. ${ }^{77}$

Elgondolkoztató, hogy 1475/6-ban a tasnádi uradalom falvai 52 Ft, maga Tasnád pedig egyedül 54 Ft adót fizetett, a zilahi uradalom tartozékát alkotó falvak összesen 38 Ft-jával szemben viszont Zilah lakossága $169 \mathrm{Ft}$ adóterhet hordozott. ${ }^{78}$ A szilágysági püspöki birtokok jövedelmének több mint fele a két mezővárosból származott.

Nem lehetett ez lényegesen másként a püspökség belső-erdélyi birtoktestein sem. Különben az 1495. évi adóelszámolás összeállító püspöki birtokok hátralékosaival kapcsolatosan nem csupán azt tartották volna megjegyzendőnek, hogy Gyulafehérvár és Galu mezőváros 480 Ftorvos és természettudomány ne fizetett be. ${ }^{79}$ Talán megkockáztatható az a feltételezés is, hogy az erdélyi püspökök gazdasági hatalma mezővárosaikon, tartományi-politikai befolyásuk viszont nagy kiterjedésű uradalmaikon nyugodott.

A fentiekből kiderülhetett, hogy a középkori Erdélyben, a vajdák mellett a gyulafehérvári püspökség tekintendő a hatalmi-politikai szerkezet másik legfontosabb helyi eleménekGazdasági súlyán kívül azért is, mert az országos politikai alakulásának függvényében gyakran változó és többnyire a király udvarban vagy magyarországi családi birtokain tartózkodó vajdákkal szemben a püspökök jelentették a hatalmi-politikai stabilitás tartományi biztosítékait. Ennek ellenére édeskevés, amit e fontos hatalmi tényező gazdasági alapjáról, társadalmi meghatározottságairól az erdélyi társadalom- vagy politikatörténet kutatói az eddigi szakirodalomból vagy a feltárt forrásokból megtudhatnak. A birtokok megszerzésére, sorsára vonatkozóan még csak akadnak oklevelek, de az erdélyi egyházi nagybirtok gazdasági tevékenységének megismeréséhez felhasználható források alig ismeretesek. Az egyházi tizedlajstromok ugyanis csak a káptalan anyagi ügyeiben engednek némi betekintést. ${ }^{80}$

A püspöki birtokok gazdálkodására, jövedelmezőségére, szervezetére vonatkozóan egyedüli használható forrásaink Várday Ferenc püspök gyulafehérvári és gyalui tisztjeinek töredékes számadásai az 1515-1524. évekből. ${ }^{81}$ Arra is kevés a remény, hogy a késő középkori gazdagabb iratanyagból további számadások és egyéb gazdasági ügyviteli iratok nagyobb számban kerülhetnek elö. Az ellenőrzött számadásokat ugyanis a középkorban általában visszaadták a számadó személynek, a gazdasági ügyintézés múló értékű iratai pedig eleve sem számíthattak tartós megőrzésre. A későbbi leszármazottak saját elődeik gazdasági iratait sem őrizték meg hosszú ideig családi levéltárukban, nemhogy az idegenekét, hanem hamarosan veszni hagyták ezeket. Ez a gyakorlat legalább akkora kárt okozott a különben sem fejlett középkori íráshasználat emlékeiben, mint amennyit a reformációt követő szekularizáció iratpusztításai. Jellemző, hogy az erdélyi jövedelmi forrásokról 1552-ben áttekintést készítő Bornemissza Pál püspök és Georg Werner királyi biztosok is kénytelenek voltak Bécsbe azt jelenteni, hogy a püspökség jövedelméről Gyulafehérváron sem a káptalanban, sem másnál nem találtak teljes kimutatást, és ezért csak azokat az iratokat csatolhatják beszámolójukhoz, amelyeket a jelenlegi officiálisok adtak kezükbe. ${ }^{82}$

\footnotetext{
${ }^{77}$ Magyar Országos Levéltár, Magyar Kamara Levéltára, Conscriptiones portarium 60. kötet..

${ }^{78}$ Tallóczy: i. m., 180-185. o.

${ }^{79}$ Engel: i. m. 149. o.

${ }^{80}$ Barabás Samu: Erdélyi káptalan tizedlajstromok. TTár 1911., 401-440. o.

${ }^{81}$ Zokm XII. 369-429. o.

${ }^{82}$ Engel: i.m., III. 15. o.
} 
Ez indokolja, hogy a további kutatás elömozdítása érdekében dolgozatunk függelékeként teljes szövegében közzétegyük a gyulafehérvári-szentmihálykői és a gyalui püspöki uradalom jövedelmeiről készült, eddig ismeretlen kimutatást. Ennek keltezetlen eredetije több helyen szétmállott, ívméretü papírfüzet, mely az erdélyi káptalan Gyulafehérváron őrzött magánlevéltárának 57. számú ládikájában található Codex authenticorum címü kézirat 207-227. lapját alkotja. E levéltár anyagához a XIX-XX. század fordulóján készített kéziratos mutató 589. lapján Beke Antal levéltáros (1838-1913) e kimutatást 1514-re keltezi, és Várday Ferenc saját kezü feljegyzésének minősítette. Az erdélyi püspökség történetéről összeállított kéziratában, mely Török Bertalannak az Erdélyi Nemzeti Múzeum Levéltárárba került gyüjteményében maradt reánk, Beke többször is hivatkozott e kéziratra Várday püspök regesztrumaként. ${ }^{83}$

Beke mindkét fentebbi megállapítása azonban két okból is helyesbítésre szorul. Először azért, mert a füzet, papírja vízjelének tanúsága szerint, bizonyosan 1546 és 1555 között Brassóban készült. Az 1544/5-ben létesített brassói papírmalom tulajdonosa, Johannes Fuchs, ugyanis csak ebben az időszakban használta készítményei megjelölésére Brassó város címerét és a saját nevére utaló rókaábrázolást. ${ }^{84}$ Másodszor azért kell elvetnünk Beke keltezését, mert az eredeti kézírásának jellege vitathatatlanul a XVI. század közepére utal.

Véleményünk szerint az alább közölt kimutatás feltehetőleg 1552 körül készülhetett; talán éppen a Bornemisza-Werner bizottság részére, és a püspöki birtokok eladományozása előtti utolsó időszakban rögzítette az eredeti állapotokat. Statileo János püspök halála (1542. április 8.) után a püspökség birtokait az erdélyi rendek a Buda török megszállását követően Erdélybe szorult királyi udvartartás céljaira rendelték ugyan, de elöírták azok korábbi állagának változatlan fenntartását. Tilalmazták, hogy azokból akár Izabella királyné is bármit eladományozzon, elzálogosítson vagy bármi módon elidegeníthessen. ${ }^{85} \mathrm{~A}$ fentebbi keltezés mellett az is felhozható, hogy Bornemisza Pálnak, akit I. Ferdinánd király Erdély püspökének kinevezett, személyes érdeke is lehetett a püspöki birtokok jövedelme felőli tájékozódás. ${ }^{86}$

\footnotetext{
${ }^{83}$ Török Bertalan gyüjteményének ezt a darabját jelenleg a Román Akadémia kolozsvári könyvtárának kézirattárában őrzik.

${ }^{84}$ Jakó Zsigmond: Az erdélyi papirmalmok feudalizmuskori történetének vázlata (XVI-XVIII. század). Studia Universitatis Babeş-Bolyai. Series Historia, 1962., fasc. 2, p. 62-66. - Uö.: Filigrane transilvănene din secolul al XVI-lea. Studia Universitatis Babeş-Bolyai. Series Historia, 1968, fasc. 1, p. 3-17.

${ }^{85}$ Szeredai Antónius: Series antiquorum et recentiorum episcoporum Transilvaniae. A. Carolinae 1790., 200-202. o. - Erdélyi Országgyülési Emlékek. I. (Szerkeszti Szilágyi Sándor.) Bp., 1875., 93., 123., 189. o.

${ }^{86}$ Szereday: i.m., 203-204. o.
} 